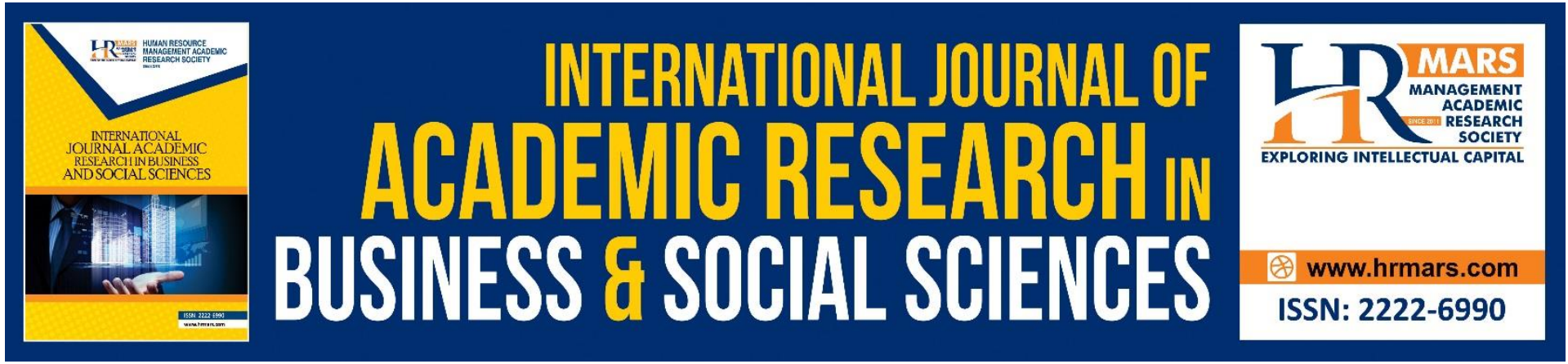

\title{
Family Visitation and Support: Facilitating Reintegration of Parolees
}

Kausalya Devi Sathoo, Fauziah Ibrahim \& Wan Shahrazad Wan Sulaiman

To Link this Article: http://dx.doi.org/10.6007/IJARBSS/v11-i7/10537

DOI:10.6007/IJARBSS/v11-i7/10537

Received: 19 May 2021, Revised: 21 June 2021, Accepted: 14 July 2021

Published Online: 28 July 2021

In-Text Citation: (Sathoo et al., 2021)

To Cite this Article: Sathoo, K. D., Ibrahim, F., \& Sulaiman, W. S. W. (2021). Family Visitation and Support: Facilitating Reintegration of Parolees. International Journal of Academic Research in Business and Social Sciences, 11(7), 813-823.

Copyright: (c) 2021 The Author(s)

Published by Human Resource Management Academic Research Society (www.hrmars.com)

This article is published under the Creative Commons Attribution (CC BY 4.0) license. Anyone may reproduce, distribute, translate and create derivative works of this article (for both commercial and non-commercial purposes), subject to full attribution to the original publication and authors. The full terms of this license may be seen at: http://creativecommons.org/licences/by/4.0/legalcode

Vol. 11, No. 7, 2021, Pg. 813 - 823

http://hrmars.com/index.php/pages/detail/IJARBSS

JOURNAL HOMEPAGE

Full Terms \& Conditions of access and use can be found at http://hrmars.com/index.php/pages/detail/publication-ethics 


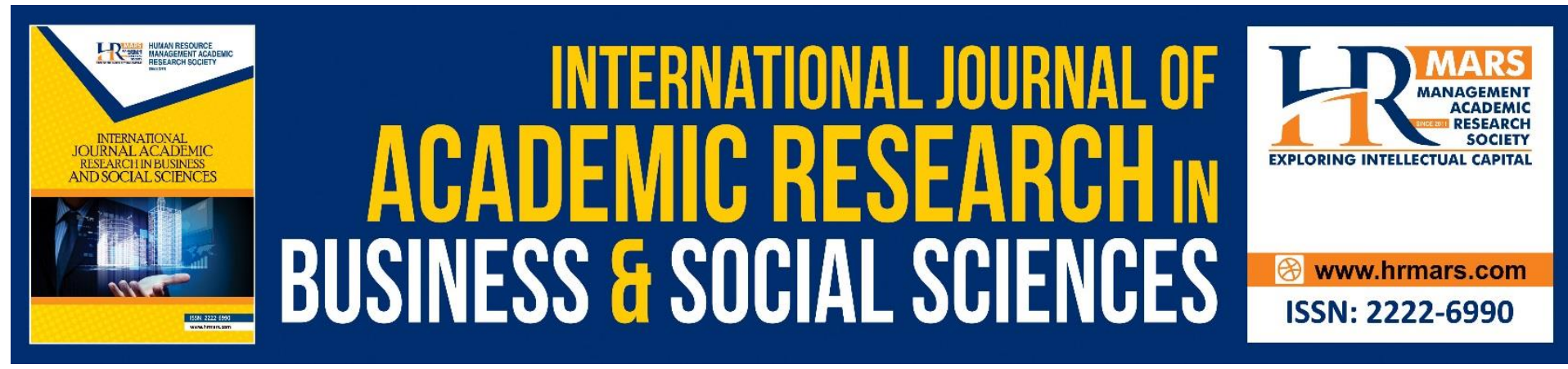

\title{
Family Visitation and Support: Facilitating Reintegration of Parolees
}

\author{
Kausalya Devi Sathoo ${ }^{1}$, Fauziah Ibrahim² \& Wan Shahrazad \\ Wan Sulaiman ${ }^{2}$ \\ ${ }^{1}$ Malaysian Prison Department, Ibu Pejabat Penjara Malaysia, Bukit Wira, \\ 43000 Kajang, Selangor, ${ }^{2}$ Center for Research in Psychology and Human Well-Being, \\ Faculty of Social Science and Humanities, The National University of Malaysia, \\ 43600 Bangi, Selangor, Malaysia
}

\begin{abstract}
This paper discusses about the prison visitation and the level of support received by parolees while serving the Parole Order. Respondents were among 240 parolees from 52 District Parole Offices throughout Malaysia. Data were collected using a questionnaire gauging the prison visit while family support was measured using the Measure of Perceived Social Support from Family and Friends. Results showed that visitation during incarceration do promise the kind of support needed by parolees from their families during release on parole. A statistically significant positive relation between family support and reintegration of parolees into the community was also found. The strong family support received by parolees ensured success in the process of reintegration into society and job security, which will eventually hinder them from becoming recidivists. Hence, efforts need to be taken to ensure and enhance family visits during imprisonment which will increase the level of family support needed to facilitate the reintegration process of parolees into the society.
\end{abstract}

Keywords: Visitation, Parolees, Reintegration, Family Support, Recidivist

\section{Introduction}

Increased incarceration over the years has been seen to have an effect on family structures becoming dismantled, leaving inmates and family members physically separated. For individuals who have no interest in penology or on those incarcerated in the prisons, it is a mind set of "lock them up and throw away the keys". But for the inmates and their families, although the separation is temporary it can be detrimental. To reduce the impact, prison inmates are allowed to be visited by family members, friends or persons given the approval. Hence, prison visitation enables inmates to maintain ties with their families and the community. Prison visitation is an important method used to strengthen inmates' social ties and motivate good behaviour in prison (Cochran \& Mears, 2013).

Visitation is an important way to maintain connections during incarceration and enhances the inmate's success, both while in prison and after release. Strengthening or re-establishing the connections is vital to reduce the recidivism rates. Inmates need interaction with caring 
people to help them confront their issues and reform themselves before re-entering community (Walker, et al., 2018). The potential promise of visitation is to help inmates maintain or restore social ties, and, in turn, to improve individuals transition from prison life back to society (Cochran, 2019). Visitation is a privilege afforded to the inmates. The Prison Department of Malaysia recognises the importance of visitations and encourages families or significant others to visit as their circumstances allow. All inmates are eligible to receive visits unless they have temporarily lost that privilege due to disciplinary action. However, there are inmates who do not have visits throughout their incarceration period for reasons such as having no family members, distance or financial issues.

There are various types of visitation for inmates. Telephone visitation is done behind a glass partition. The inmates and the other person have a phone which can be used to talk to one another but the glass separates them. For families who are unable to be physically present at the prison facility, inmates can use designated phones to make calls to their family members or friends. Phone cards are available for purchase in the prisons which enables them to make calls to their loved ones. However, in recent years and especially during the COVID19 pandemic, family focused visitation practices are put on hold and a new form of visitation through video or telephone technology has emerged. Video or telephone visitation although not common is a form of visitation done at the comfort of one's own home. Another type of visit is the contact visit. Contact visitation is when the visiting party have access to physical contact with inmates. This form of visits is very popular among inmates and families as it enables physical presence of both parties. However, during such visitation, the prison officers will be monitoring the session which is carried out within sight and within hearing.

In addition to visitation, there is another type of communication for family and others to remain connected to inmates during incarceration, which is through mail and telephone calls. All inmates are allowed to receive any number of mails. Nevertheless, these mails go through a vetting process. The limitation on the content of the written communication is that it should not contain anything that is a threat or potential threat such as contents regarded as disrupting the security of the prison, crime related discussion or plan. While it is important for every offender to maintain connections with the family and significant others during incarceration, the safety and security of staff, inmates and visitors are pivotal. To ascertain safety, all visitors are subject to a preliminary search by electronic surveillance instruments or physical search. If there is a suspicion of violation on contraband, a more thorough search may be conducted. It is clearly stated that all visitors are subject to search or screening as posited in Rule 99(3), Prison Regulations 2000. This is to ensure no contraband is passed over to the inmates which may pose unduly threat to the prison security level. Visitors who refused to be searched may be denied the privilege to visit. Besides that, all visitors are also required to be appropriately dressed during the visits. Those who are not properly and decently dressed may not be allowed to visit by the Officer-in-Charge of the prison institution (Prison Regulations, 2000).

\section{Literature Review}

Although incarceration is viewed as a necessary means of public protection, research indicates that it is not an effective option in terms of either costs or outcome. There is great impact of incarceration on individuals and families. There is growing recognitions that children are impacted by parental incarceration (Brooks \& Bainham, 2004). Children with an 
incarcerated parent were at increased risks of poorer outcomes, including poorer mental health with psychological strain, lower levels of education and employment attainment, increased antisocial behaviour including involvement in criminal activities as well as economic hardship (Murray \& Farrington, 2005; Raeder, 2012; Schaler, et al., 2013). These social, economic and well-being costs indicate that policy makers need to take action. However, research suggests that parent-child bond and family social support system play significant roles in overcoming these challenges and success in life. As for inmates, besides other factors after release such as employment, housing, health and social support (Naser \& La Vigne, 200; Bales \& Mears, 2008; Derkzen, et al., 2009; Mears, et al., 2012; Barrick, Lattimore \& Visher, 2014; Duwe \& Clark, 2014), successful offender re-entry into the community is influenced by prison visitation (Cid, et al., 2012). Strong social networks may provide protective mechanisms that function to prevent criminal relapse after release from incarceration (Bales \& Mears, 2008; Barrick, Lattimore \& Visher, 2014).

Extensive studies have shown that family support and family ties are the one most important aspect contributing to an ex-inmate's successful re-entry into the society. As a key resource of social support, prison visitation allows inmates to interact and communicate with their loved ones over a significant period of time (Christian, 2005; Visher, 2013). Such meaningful contact can help to minimise the pain of imprisonment by providing inmates with an important coping resources. Visits also provide inmates and visitors a chance to maintain or rebuild relationships. It is also an important opportunity to plan for release and to address other critical reintegration issues and challenges. To begin, there are several pathways linking visitation to reductions in misconduct. Visitation alleviates acute feelings of isolation associated with incarceration (Blevins, et al., 2010). Visitation may strengthen social bonds and enable inmates to maintain connections with members of their family and community. Research findings by Cochran (2012) further confirms that inmate visitation can reduce misconduct in prison. In particular, consistent visitation is associated with less prison misconduct. It was also found that quality prison visitation is essential in improving re-entry outcomes (Booth, 2018).

Further, prison visits reduce depressive symptoms in women and adolescent. There was also some evidence of decrease in rule-breaking behaviour. Some studies have concluded that visits are associated with modest improvements in in-prison behaviour. Results from research conducted by Bales and Mears (2008) show that prisoners who were visited had significantly lower recidivism rates and lived longer in the community without re-offending than those who were not visited. It was also found that more frequent visits from family seems to play a role with a more rapid decline in conduct issues (Siennick, Mears \& Bales, 2013). Therefore, there are benefits for children and parents in nurturing parent-child relationships during incarceration. What is clear is that the effects of prison visits on inmates are complex (De Claire \& Dixon, 2015; Siennick et al., 2013). Visits from children can be associated with better mental health through reducing isolation and supporting relationships (Cochran \& Mears, 2013; De Claire \& Dixon, 2015).

Profoundly, Mitchell, et al., (2016) using the meta-analysis study to assess the effect of prison visitation on the odds of recidivism after release further indicates that prison visitation generates modest decrease in post release offending. It was found that a decreased risk of re-incarceration and new conviction was associated with prison visitation. Findings from a 
research conducted by Casey, Copp and Bales (2020), reveal that inmates who received visits were no less likely to recidivate than their counterparts. Yet, it was highlighted that among those received visits were less likely to recidivate. However, while other studies found no effect, others have found visits to be associated with negative effects (Cochran \& Mears, 2013; Siennick et al., 2013). When inmates do not have access to visitors, the public may be concerned about an inmate's re-entry into the society.

\section{Method}

\section{Respondents}

Respondents were 240 male parolees from 52 District Parole Office all over Malaysia. Majority of them were bachelors (49.2\%), with a lower secondary school education and below $(91.2 \%)$. About $78.8 \%$ of the respondents were in the age category of 40 years and below.

\section{Instrument}

A set of questionnaire was used to collect data from respondents. The first part of the questionnaire consisted demographic profile of parolees to obtain background particulars of parolees. The second part of the questionnaire was the measure of Perceives Social Support from Family and Friends. This scale was developed by Procidano and Heller (1983) to assess the support received from family and friends. It consists of 37 items on a scale in which the items are rated through 1-4 from very not agreeable to very agreeable. The internal consistency reliability analysed by Cronbach Alpha was .70. The third part of the questionnaire was the Reintegration of Parolees into the Society. Items on reintegration of parolees into the society were developed based on vast literature review regarding the subject matter. A number of 26 items were developed on a scale in which the items are rated through 1-4 from very not agreeable to very agreeable. The internal consistency reliability analysed by Cronbach Alpha was .80.

\section{Procedure}

The instruments were administered in the State Parole Offices. The parolees were briefed on the purpose of the research. They were assured that the information they provided will be secured and that they were free to participate in the research. The parolees agreed to participate in the session which took approximately 30 to 40 minutes to complete the questionnaire.

\section{Data Analysis}

Data was analysed using descriptive statistics and correlational analysis. Statistical analysis was conducted using SPSS 19.0. An alpha level of .01 was used for statistical analysis.

\section{Results}

As seen in Table 1, 92.5\% parolees received visits while incarceration while only $7.5 \%$ failed to enjoy such privilege. On the frequency of visits, $59.2 \%$ were often visited while $33.3 \%$ were seldom visited. 
Table 1: Visitation during Incarceration

\begin{tabular}{lcc}
\hline Family Visits & No. of Inmates & Percentage (\%) \\
\hline Yes & 222 & 92.5 \\
No & 18 & 7.5 \\
& & \\
\hline Frequency of visits & No. of Inmates & Percentage (\%) \\
\hline Never & 18 & 7.5 \\
Seldom & 80 & 33.3 \\
Often & 142 & 59.2
\end{tabular}

Table 2 indicates the type of assistance received by parolees while serving their Parole Order in the society. About $87.1 \%$ of the parolees were provided accommodation facilities by their family while $12.1 \%$ of the parolees resided in halfway houses. Only $0.8 \%$ employers provided such facility to accommodate parolees serving the Parole Order. Pertaining to employment, about $50.0 \%$ of employment opportunity was secured by families. About $43.3 \%$ of job opportunity were assisted by Parole Officers, while only $6.7 \%$ found employment by themselves.

Table2: Types of Assistance

\begin{tabular}{lcc}
\hline Accommodation & No. of parolees & Percentage (\%) \\
\hline Family & 209 & 87.1 \\
Employer & 2 & 0.8 \\
Halfway House & 29 & 12.1 \\
& & \\
\hline Employment & No. of parolees & Percentage (\%) \\
\hline Family & 120 & 50.0 \\
Parole Officer & 104 & 43.3 \\
Self & 16 & 6.7 \\
\hline
\end{tabular}

It was found that there was a statistically significant positive relation between family support with the reintegration of parolees into the society $(r=0.3-. p<0.01)$ as shown in Table 3.

Table 3: Pearson Correlation between family support and reintegration into the society

Family support $\quad .30 * *$

**Correlation is significant at the 0.01 level

\section{Discussion}

The results of this study indicate that imprisonment does not totally tarnish ties between inmates and families although there is some impact towards it. Majority of the inmates while serving prison sentence continuously received visits from families. The results clearly support the findings by Christian (2005) and Visher (2013) who found that prison visitation allows inmates to interact and communicate with their loved ones. Such meaningful contact minimises the pain of imprisonment and above all, it is an important opportunity to plan for release and to address other critical reintegration issues and challenges. Frequent family visits assist parolees in coping with the difficulty of other emerging needs upon release. Nevertheless, a noticeable of $7.5 \%$ of inmates did not receive any form of visits. Although the benefits of visitation have been theoretically and empirically established, studies on prison 
visits have consistently reported that only half of prisoners receive visits (Mears et al., 2012; Duwe \& Clark, 2013). There is a possibility that travel distance decreases the likelihood of visitation besides other reasons such as financial issues, strained relationships and incidents of families disowning the inmates once incarcerated. For these inmates, effort is needed to reconnect them with their families or with significant others to ease the reintegration process. Accommodation has been identified as one of the key factor in reducing reoffending, thus reducing recidivism. Living in a stable and supportive accommodation, such as with family is strongly associated with success throughout the post release period (Baldry, McDonnell, Maplestone \& Peeters, 2001). Various studies have established that securing adequate housing for ex-offenders can have a significant impact on rates of recidivism (Homeless Link, 2011; Bells \& Wilson, 2017). The findings show that $87.1 \%$ of family provided accommodation facility to parolees while serving the Parole Order, while others reside in halfway houses managed by the Prison Department $(12.1 \%)$ or housing facilities arranged by employers (0.8\%). A decent accommodation ensures a decent lifestyle which ensures refraining from crime.

Securing a job is another important requirement to be fulfilled for inmates who will be released on Parole Order. Although parolees use multiple strategies to find a job, including the service of parole officers and themselves, the most common and useful resource is through family assistance. About $50.0 \%$ of the parolees were assisted by family in securing employment opportunity. Family's assistance in obtaining jobs plays a crucial role as most former inmates experience difficulty in finding a job after release (Visher, Debus-Sherill \& Yahner, 2008). Employment is an important component to the reintegration process. Even more than providing a steady source of income, jobs can provide a sense of structure and responsibility to parolees as they struggle to reintegrate into the community. This is further endorsed by Social Control Theory developed by Travis Hirschi which asserts that ties to family serve to diminish one's propensity for deviant behaviour. Hence, this theory posits that crime occurs when such bonds are weakened or not well established. According to Hirschi, these bonds are based on attachment to those within and outside of the family, commitment to activities in which an individual has invested time and energy, involvement in positive activities and finally belief in wider social values. These four aspects of social control are thought to interact to insulate an individual from criminal involvement (Siegel \& McCornick, 2006)

According to Berg and Huebner (2011); Cochran and Mears (2013); Mears and Cochran and Cullen (2015), by establishing family ties, prison visitation helps prisoners in accessing necessary support needed during the re-entry period such as housing and employment opportunity. Obviously in this study, the family's support in providing accommodation and employment opportunity demonstrated the significant support needed by parolees in ensuring success of the reintegration process. It was also found that there was a statistically significant positive relation between family support and the reintegration of parolees into the community. Social support, especially family support has found to contribute to the formation of pro-social identities (Braithwaite 1989). Hence, Social Bonds Theory recognises this positive situation of conformity to the existence of ties to family and employment. Ward and Maruna (2007) found that when these bonds are absent, individual continue to engage in crime because they have nothing to lose. Thus, involvement and commitment of parolees in employment may be a protective factor against reoffending (Maruna \& Toch, 2005). This 
finding is further endorsed through research conducted by Gojkovic, Mills and Meek (2012:11) on prisoners in their claiming statement that:

"If you take an individual from out of the community and you put them in prison, what society doesn't understand is that he's probably had a job, he's probably had transport, he's probably had a flat. You take him out, put him in prison, he loses all of that. Now if he was having problems before, could you imagine the amount of problems he's going to have when he's now released and he hasn't got nothing... And then they wonder why do people commit crimes in a certain time after they leave prison?

Although the responsibility to bring positive changes rest heavily upon a parolee, it is clear evidence that without the support of the family, such changes may be impossible. Therefore, we need to improve visitation policies and approaches because we know that social support is critical in helping ex-offenders make that transition successful from prison to the community. Focusing on developing the social support needed by parolees will greatly facilitate and enhance the effectiveness of the reintegration process. The larger social support network that the offender has, the greater the public safety benefits. People who are not abandoned have a much chance of success when they go out from prison or while serving Parole Order in the community.

Hence, prison visitation is one such experiences that is interesting to scholars, practitioners and policy makers alike in part because of the potential promise visitation to help inmates maintain or restore social ties and in turn to improve individual's transitions from prison life back to society. To further ensure continuous support once the inmates are on Parole Order and released indefinitely, recommendations are suggested to the Prison Department which will continue to ensure strong ties between families and inmates that could reduce the tendency of inmates returning to crime once they are released from prison. Reducing common barriers to visits such as travel distance and travel costs could be addressed by housing inmates closer to home. Increasing visiting hours and keeping them consistent will increase the frequency of visits which will definitely ensure quality bonding. Simplifying complex regulations, improving visiting facilities and enhancing the infrastructure will provide conducive and visitor friendly environment. Besides that, introducing feasible alternatives to visits will further increase family connections and ties among inmates and family members.

\section{Conclusion}

Incarceration by its very nature involves separation of an individual from their family, friends and usual networks. Creating a balance between the justice system in achieving its aim and the intent of families is a complex process. Crime is not only a law enforcement problem or a correctional problem. Often it is proven that effort to control crime is much more successful when there is involvement from the community. Incarceration causes disruption to the relationship between inmate and family and individuals often struggle to resume their lives once they are released. To overcome such setback, communication through visitation is important to maintain relationships and alleviate some of the issues and challenges on reintegration. Therefore, it is important and critical to recognise the potential impact of visitation on the success of the Parole System. The success of an inmate in the real world has been found to correlate positively and significantly with maintenance of important relationships during his/her incarceration. Maintaining an inmate's family and community 
relationships through enhancing visiting services and program as well as increasing the frequency and quality of visits improves an inmate's behaviour in the correctional facilities. This helps to reduce recidivism among inmates upon their release.

As the gateway to imprisonment, prison and correctional facilities can serve as a crucial role in facilitating or impeding communications among family members. Therefore, facilities in the visitation policies and practices should be family focused to maintain and foster relationship. By maintaining such relationship, it is hoped that inmates leaving the prison will receive support from the public, most importantly from their families to keep them away from crime. Visitation illuminates the complex needs of parolees to facilitate the reintegration process while serving the Parole Order and thereafter. This pivotal effort will undoubtedly help to reduce recidivism rates among ex-inmates. Undoubtedly, by providing the support needed, families serve as the anchor in the community for parolees and ex-offenders in breaking the crime cycle and ensuring public safety. Findings from this research contribute and reemphasize that prison visitations is significant to maintain family contact and support which later facilitates the reintegration process of parolees into the society. More research is warranted to better understand the contribution of prison visitations as protective factor in curbing reoffending and reducing recidivism rate amongst parolees.

\section{Reference}

Baldry, E., McDonnell, D., Maplestone, P., \& Peeters, M. (2003). Ex-prisoners and accommodation: What bearing do different forms of housing have on social reintegration? RMIT NATSEM Research Centre: Australian Housing and Urban Research Institute.

Bales, W. D., \& Mears, D. P. (2008). Inmate Social Ties and the Transition to Society: Does Visitation Reduce Recidivism? Journal of Research in Crime and Delinquency, 45(3), 287321.

Barrick, K., Lattimore, P. K., \& Visher, C. A. (2014). Re-entering Women: The Impact of Social Ties on Long Term Recidivism. The Prison Journal, 94(3), 279-304.

Bells, A., \& Wilson, W. (2017). Housing Support for ex-offenders (England \& Wales). Briefing Paper 2989 (17).

Berg, M. T., \& Huebner, B. M. (2011). Reentry and the ties that bind: An examination of social ties, employment, and recidivism. Justice Quarterly, 28(2), 382-410.

Blevins, K. R., Listwan, J. S., Cullen, F. T., \& Jonson, L. C. (2010). A general strain theory of prison violence and misconduct: An integrated model of inmate behavior. Journal of Contemporary Criminal Justic, e 26(2), 148-166.

Booth, N. (2018). Family Matters: A Critical Examination of Family Visits for Imprisoned Mothers and their Families. Prison Service Journal. http://hdl.handle.net/2086/15647

Braithwhaite, J. (1989). Crime, Shame and Reintegration. Cambridge: Cambridge University Press.

Brooks-Gordon, B., \& Bainham, A. (2004). Prisoners' families and the regulation of contact. The Journal of Social Welfare \& Family Law, 26(3), 263-280.

Casey, W. M., Copp, J. E., \& Bales, W. D. (2020). Releases from a Local Jail: The Impact of Visitation on Recidivism. Criminal Justice Policy, (32(4), 427-441.

Christian, J. (2005). Riding the bus: Barriers to prison visitation and family management strategies. Journal of Contemporary Criminal Justice, 21(1), 31-48. 
Cid, J., Pedrosa, A., Ibàñez, A., \& Martí J. (2021). Does the Experience of Imprisonment Affect Optimism About Reentry?. The Prison Journal 101(1). 0032885520978476.

Cochran, J. C. (2012). The ties that binds or the ties that breaks: Examining the relationship between relationship between visitation and prisoner misconduct. Journal of Criminal Justice, 40(5), 433-440.

Cochran, J. C. (2019). Inmate Social Ties, Recidivism and Continuing Question About Prison Visitation. In Hutton, M., Moran, D. (eds). The Palgrave Handbook of Prison and the Family. Palgrave Studies in Prisons and Penology. Palgrave MacMillan, Cham.

Cochran, J. C., \& Mears, D. P. (2013). Social isolation and inmate behavior: A conceptual framework for theorizing prison visitation and guiding and assessing research. Journal of Criminal Justice, 41(4), 252-261.

De Claire, K., \& Dixon, L. (2017). The effects of prison visits from family members on prisoners' well-being, prison rule breaking, and recidivism: A review of research since 1991. Trauma, Violence, \& Abuse, 18(2), 185-199.

Derkzen, D., Gobeil, R., \& Gileno, J. (2009). Visitation and post-release outcome among federally-sentenced offenders. Ottawa: Correctional Service of Canada.

Duwe, G., \& Clark, V. (2014). The effects of prison-based educational programming on recidivism and employment. The Prison Journal, 94(4), 454-478.

Gojkovic, D., Mills, A., \& Meek, R. (2012). Accommodation for ex-offenders: Third sector housing advice and provision. Third Sector Research Centre, Working Paper 77.

Homeless Link. (2011). Better Together: Preventing Reoffending and Homelessness. London: Homeless Link.

Maruna, S., \& Toch, H. (2005). The impact of imprisonment on the desistance process. Prisoner reentry and crime in America, 139-178.

Mears, D. P., Cochran, J. C., \& Cullen, F. T. (2015). Incarceration heterogeneity and its implications for assessing the effectiveness of imprisonment on recidivism. Criminal Justice Policy Review, 26(7), 691-712.

Mears, D. P., Cochran, J. C., Siennick, S. E., \& Bales, W. D. (2012). Prison visitation and recidivism. Justice Quarterly, 29(6), 888-918.

Mitchell, M. M., Spooner, K., Jia, D., \& Zhang, Y. (2016). The effect of prison visitation on reentry success: A meta-analysis. Journal of Criminal Justice, 47, 74-83.

Murray, J., \& Farrington, D. P. (2005). Parental imprisonment: effects on boys' antisocial behaviour and delinquency through the life-course. Journal of Child Psychology and psychiatry,y 46(12), 1269-1278.

Naser, R. L., \& La Vigne, N. G. (2006). Family support in the prisoner re-entry process: Expectations and realities. Journal of Offender Rehabilitation, 43(1), 93-106.

Prison Regulations. (2000). Prison Department of Malaysia.

Raeder, M. (2012). Making a Better World for Children of Incarcerated Parents. Family Court Review, 50(1), 29-35.

Schaler, R., Gerrity, E., Ruhland, E., \& Wheeler, M. (2013). Children with Incarcerated ParentsConsidering Children's Outcomes in the Context of Family Experiences. St. Paul, MN: University of Minnesota.

Siegel, L. J., \& McCormick, C. (2006). Criminology in Canada: Theories, Patterns, and Typologies ( $3^{\text {rd }}$ ed.). Toronto: Thompson.

Siennick, S. E., Mears, D. P., \& Bales, W. D. (2013). Here and gone: Anticipation and separation effects of prison visits on inmate infractions. Journal of Research in Crime and Delinquency, 50(3), 417-444. 
Visher, C. A. (2013). Incarcerated fathers: Pathways from prison to home. Criminal Justice Policy Review, 24(1), 9-26.

Walker, S., Lancaster, K., Stoové, M., Higgs, P., \& Wilson, M. (2018). "I Lost Me Visits" A Critical Examination of Prison Drug Policy and Its Effects on Connection to Family for Incarcerated Young Men with Histories of Injecting Drug Use. Contemporary Drug Problems, 45(3), 303-328.

Ward, T., \& Maruna, S. (2007). Rehabilitation: Beyond the Risk Assessment Paradigm. London, UK: Routledge.

Visher, C., Debus-Sherrill, S., \& Yahner, J. (2008). Employment After Prison: A Longitudinal Study of Releases in Three States. Washington, DC: The Urban Institute. 